\title{
A HATÁRON TÚLI MAGYAROK KULTURÁLIS HÁLÓZATA
}

Dr. Bali János

\section{ABSZTRAKT}

A rövid tanulmány célja átfogó képet adni a határon túl élő magyarok kulturális hálózatáról. Írásomban kitérek a térbeliség kérdésére, vagyis, hogy a Kárpát-medence magyarok lakta külhoni régióiban milyen sűrű a kulturális intézményhálózat? Ez(ek) a hálózat(ok) mennyire függetlenek Magyarországtól, másképp fogalmazva, az anyaország mennyiben vállal szerepet a határon túli magyarok kulturális hálózatának alakításában, fejlesztésében? A legfőbb intézménytípusok (könyvtár, múzeum, kultúrház, felsőoktatási intézmény, egyéb kulturális intézmény és civil szervezet) mentén mutatom be a hálózatosodás helyzetét. Megállapítom, hogy 2010-től, mióta Magyarország Kormánya kiemelt feladatának tartja a nemzetpolitikát, a határon túli magyarok kulturális hálózata megerősödött. A korábban is létező, megannyi informális kapcsolatra formális, intézmények közötti kapcsolatok sokasága épült. A határon túli magyarok kulturális hálózata az anyaországgal szoros kapcsolatban vált mind láthatóbbá.

\section{BEVEZETÉS}

A tanulmány, a rendelkezésre álló szűk terjedelmi keretek miatt, a kulturális hálózatot a formális intézményeken keresztül mutatja be. Az informális hálózatok szerepének vizsgálata csak egy új, átfogó kutatás eredményeként valósulhat meg. ${ }^{1} \mathrm{~A}$ címben is szereplő „kulturális” jelzőt annak szűkebben vett értelmében használom, és nem tekintem részének a „múvészeti” és a „sport” kifejezések által lefedett tartalmakat, így a színházakat, mozikat, koncerttermeket, galériákat, sportegyesületeket sem, hiszen azok önálló hálózatokká szerveződtek az elmúlt években, évtizedekben. Mellőzöm a közoktatással, közneveléssel kapcsolatos hálózatok kérdését is, amely ugyancsak önálló tanulmányt érdemelne. Nem térek ki arra sem, hogy a kulturális hálózat milyen módon alakul az online térben, pedig érdemes lenne megvizsgálni azt is, hogy a digitalizáció térnyerésével, a világhálónak az életszervezésben tapasztalható egyre jelentősebb szerepével párhuzamosan melyek azok

${ }^{1}$ A téma nagyságát és szerteágazóságát mutatja, hogy még a kalotaszegi cigányzenészek kulturális hálózatáról is önálló PhD-disszertáció született 2007-ben, Id.: KÖNCZEI Csongor: A kalotaszegi cigányzenészek társadalmi és kulturális hálózatáról. Budapest, ELTE BTK, 2007. http://doktori.btk.elte.hu/folk/konczei/diss.pdf 
a tevékenységek, amelyeknél a fizikai jelenléten alapuló formák visszaszorultak. ${ }^{2}$ Melyek azok a szempontok tehát, amelyeken keresztül a témát fel szeretném vázolni? Írásomban kitérek a térbeliség kérdésére, vagyis, hogy a Kárpát-medence magyarok lakta külhoni régióiban milyen sűrű a kulturális intézményhálózat? Ez(ek) a hálózat(ok) mennyire függetlenek Magyarországtól, másképp fogalmazva, az anyaország mennyiben vállal szerepet a határon túli magyarok kulturális hálózatának alakításában, fejlesztésében? A finanszírozás kérdésére ugyanakkor hangsúlyosan nem térek ki, hiszen az adatok nagy része titkos vagy szenzitív.

\section{KÖNYVTÁRAK}

Az Elektronikus Információszolgáltatás (EISZ) Nemzeti Program által épített kulturális hálózatnak immár ${ }^{3} 34$ határon túli intézmény a tagja. Olyan partnerek csatlakoztak a kezdeményezéshez, amelyek elsődlegesen könyvtárak (szak- vagy közkönyvtárak) vagy szakmai feladatellátásuk része a könyvtári szolgáltatás biztosítása (múzeumok, felsőoktatási intézmények). A határon túli magyar könyvtári hálózat ennél persze jóval szélesebb. Három régióról van részletes képünk, így Kárpátalját, Erdélyt és Vajdaságot nézzük meg közelebbről. Áttekintésünkben a magyarok által (is) lakott településeket vesszük sorra, ahol a könyvtárban magyar nyelvű könyvekhez és sajtótermékekhez juthat az érdeklődő. Kárpátalján összesen 38 könyvtár található, amely lefedi a magyarok lakta járások településeinek többségét. ${ }^{4}$ Erdélyben a magyar könyvtári hálózat jelentősen nagyobb és összetettebb, jellemzően területi hatóköri és fenntartási szintekre tagolódik (községi, megyei, városi, municípiumi könyvtárak). A 379 könyvtárba már az egyetemi könyvtárakat is beleszámoltuk. ${ }^{5} \mathrm{~A}$ legtöbb könyvtár a kulturális és városközpontokban

\footnotetext{
2 Különösen aktuális a kérdés a 2020 tavaszán kicsúcsosodó járványügyi veszélyhelyzet alkalmával. Például, az Ausztriai Magyar Pedagógusok Egyesülete kénytelen volt online formában megtartani a 11. alkalommal meghirdetett Mesemondó- és Szavalóversenyét. Az eredeti 168 jelentkezőből így is maradt 151 fiatal, akik videón küldték el produkciójukat. Közülük 56-an Magyarországról, 66-an Vajdaságból, Felvidékről és Erdélyből, 17-en Ausztriából neveztek, továbbá 8-an Németországból és 4-en Spanyolországból küldték el jelentkezésüket. https:// amaped.at/hirek/mesemondo-es-szavaloverseny-az-ausztriai-magyar-pedagogusok-egyesuletenel/

3 http://eisz.mtak.hu/images/dokumentumok/intezmenyi lista hataron tul.xlsx

${ }^{4} \mathrm{~A}$ nagyobb városokban több könyvtár is működik, így Beregszászon 4, amibe nem is számoltuk bele a más profilú intézmények könyvtárait (pl. II. Rákóczi Ferenc Kárpátaljai Magyar Főiskola). A következő településeken rendelkeznek saját könyvtárral: Nagyszőlős, Técső, Nagydobrony, Nagyszőlős, Gyula, Tiszabökény, Nagypalád, Fancsika, Salánk, Verbőc, Tiszaújhely, Ungvár, Tiszaújlak, Batár, Királyháza, Beregszász, Munkács, Dercen, Izsnyéte, Barkaszó, Fornos, Korláthelmec, Kisdobrony, Aknaszlatina, Kereknye, Gálocs, Csongor, Tarnóc, Salamon, Császlóc, Palágykomoróc, Téglás, Szernye, Asztély

${ }^{5}$ A romániai magyarság által lakott települések, ahol müködik könyvtár: Uzon, Zilah, Máramarossziget, Bethlen, Nagybánya, Krasznabéltek, Segesvár, Arad, Nagyszeben, Csíkszentmárton, Belényes, Gyergyóremete, Fejér Miklós Zabola, Beszterce, Maroshévíz, Margitta, Óradna, Tasnádszántó, Csíkszereda, Borszék, Kézdiszentlélek, Oroszhegy, Óbéb, Igazfalva, Oklánd, Parajd, Csíkszentdomokos, Csíkszentsimon, Székelyandrásfalva, Salamás, Újszékely, Gyergyóújfalu, Siménfalva, Vasláb, Ákosfalva, Ádámos, Fehéregyháza, Magyaró, Küküllővár, Cintos, Magyarforró, Szászbogács, Alsógáld, Balavásár, Magyarlapád, Mezőbánd, Székelykocsárd, Bátos, Miriszló, Marosbogát, Marosnagylak, Mezőcsávás, Tompaháza, Maroskece, Torockó, Nyárádkarácson, Szépmező, Maroskeresztúr, Felvinc, Nyárádremete, Nagyernye, Gyulakuta, Nyárádgálfalva, Vámosgálfalva, Makfalva, Marossárpatak, Gernyeszeg, Csermő, Görgényszentimre, Angyalkút, Székelyhodos, Gyorok, Nyárádmagyarós, Nagyiratos, Fakert, Szásznádas, Tőzmiske, Havad, Mezőbodon, Németpereg,l Backamadaras, Nagypél, Mezőrücs, Németság, Marosszentkirály, Székesút, Marosszentgyörgy, Selénd, Kerelőszentpál, Szinte, Marosszentanna, Sofronya, Mezősámsond, Vinga, Marosfelfalu, Nagyzerénd, Csíkfalva, Zimándújfalu, Székelyvécke, Vajdaszentivány, Érábrány, Vedresábrány, Érbogyoszló,Erzsébetbánya, Vámosláz, Hosszúmező, Szentjobb, Koltó, Érkörtvélyes, Kővárremete, Felsőderna, Bihardiószeg, Szalacs, Érsemjén, Értarcsa, Tóti, Ákos, Érszőllős, Egri, Bihar, Érendréd, Bors, Börvely, Hegyközcsatár, Bogdánd, Illye, Batiz, Köröskisjenő, Kaplony, Fugyivásárhely, Érkávás, Mezőszakadát, Oláhcsaholy, Váradszentmárton, Királydaróc, Biharszentandrás, Nagykolcs, Mezőtelegd, Szamosdob, Keményfok, Pusztadaróc, Madarász, Mezőfény, Tenke, Halmi, Hadad, Szászfalva, Lázári, Rév, Mikola, Kismajtény, Feketekápolna, Szatmárudvari, Várasfenes, Magyarremete, Szatmárpálfalva,
} 
található. Kolozsváron például az Octavian Goga Megyei Könyvtár több fiókkönyvtárat is fenntart az egyes városnegyedekben. Vajdaságban 115 könyvtár biztosítja az írott magyar kultúrához való hozzáférést. ${ }^{6}$ Itt az úgynevezett népkönyvtárak egy-egy jelentősebb központban találhatóak (pl. Nagykikinda, Topolya, Zombor), amelyek a környező kisebb településeken fiókkönyvtárakat tartanak fenn. A határon túli magyar könyvtári hálózat fontos szerepet játszik a helyi közmúvelődésben, ami a szülőföldön történő megmaradás és magyarként való boldogulás záloga. A kisebb települések nagy részén a könyvtár, a kultúraközvetítést és identitáserősítést biztosító intézmények sorában - a templom, az iskola és a kultúrház mellett - jelentős szerepet játszik a helyi közösségek építésében. Ugyanakkor megállapítható, hogy jelentős területi különbségek tapasztalhatók e könyvtárak között, mind a magyar nyelvű könyv- és folyóirat-ellátottságban, mind a digitalizáció előrehaladottságában. Van, ahol még a legkülönfélébb műfajú nyomtatott könyvekre lenne szükség, máshol már a digitális tartalmakhoz való hozzáférés kiszélesítése a cél.

\section{MÚZEUMOK}

Bár Magyarországon az egyes országos múzeumoknak és közgyüjteményeknek egyre szélesebb határon túli hálózati kapcsolatai vannak7, átfogó Kárpát-medencei hálózat építését formálisan a Magyar Vidéki Múzeumok Szövetsége (MVMSZ) kezdte. A kecskeméti székhelyű szervezet 2019. március 14-én fogalmazta meg felhívását, miszerint a már meglévő 63 rendes és pártoló tag mellett várják a határon túli muzeális intézmények

\footnotetext{
Mezőpetri, Szilágypér, Piskolt, Apanagyfalu, Érszakácsi, Magyarnemegye, Szaniszló, Felőr, Alsószopor, Teke, Mezőterem, Sajóudvarhely, Vetés, Szentmáté, Szatmárhegy, Galacfalva, Szászlekence, Árpástó, Váralmás, Apáca, Benedekfalva, Botfalu, Kémer, Bodola, Kárásztelek, Krizba, Kraszna, Földvár, Cigányi, Höltövény, Ipp, Olthévíz, Magyarkecel, Homoród, Szilágynagyfalu, Szilágybagos, Ürmös, Szilágyperecsen, Alsórákos, Szilágyszeg, Sárkány, Szilágysámson, Tatrang, Sarmaság, Keresztvár, Varsolc, Szásztyúkos, Bálinc, Újszentes, Gyér, Végvár, Újvár, Ajton, Egeres, Apahida, Kisbács, Bonchida, Búza, Magyarkályán, Kiskalota, Pusztakamarás, Magyarkapus, Kajántó, Kolozs, Magyarszarvaskend, Erdőfelek, Szászfenes, Gyeke, Magyargorbó, Gyalu, Körösfő, Felsőzsuk, Aranyoslóna, Magyargyerőmonostor, Mikeháza, Szentmihály, Várfalva, Magyarpalatka, Tordaszentlászló, Kalotaszentkirály, Szék, Magyarszovát, Tordatúr, Bálványosváralja, Aranyosegerbegy, Borsaújfalu, Sepsiszentgyörgy, Kézdivásárhely, Barót, Kovászna, Nagyajta, Árkos, Nagybacon, Bölön, Sepsibodok, Nagyborosnyó, Barátos, Bardóc, Bereck, Szentkatolna, Kökös, Kommandó, Esztelnek, Gelence, Gidófalva, Hidvég, Illyefalva, Lemhény, Mikóújfalu, Maksa, Ozsdola, Kézdiszentkereszt, Réty, Torja, Sepsikőröspatak, Előpatak, Vargyas, Zágon, Etéd, Szentábrahám, Karcfalva, Kápolnásfalu, Gyergyócsomafalva, Korond, Kozmás, Székelyderzs, Csíkdánfalva, Oroszhegy, Felsőboldogfalva, Szépviz, Galócás, Szárhegy, Lövéte, Gyimesközéplok, Gyimesfelsőlok, Farkaslaka, Homoródalmás, Bögöz, Nagyenyed, Gyulafehérvár, Szászsebes, Marosvásárhely, Csíkrákos, Marosújvár, Dicsőszentmárton, Balázsfalva, Fogaras, Szecseleváros, Aranyosgyéres, Dés, Szamosújvár, Székelyudvarhely, Gyergyószentmiklós, Kolozsvár, Nagykároly, Nagyvárad, Élesd, Szászrégen, Retteg, Csernáton, Szatmárnémeti, Temesvár, Torda, Nagyszalonta, Brassó, Kapnikbánya, Szinérváralja, Misztótfalu, Sülelmed, Radnót, Marosludas, Nyárádszereda, Erdőszentgyörgy, Nagysármás, Szováta, Tövis, Kisjenő, Kürtös, Pankota, Ópécska, Újszentanna, Borossebes, Felsőbánya, Érmihályfalva, Székelyhíd, Erdőd, Sárköz, Tasnád, Szilágycseh, Zsibó, Szilágysomlyó, Kőhalom, Medgyes, Lugos, Detta, Gátalja, Zsombolya, Nagyszentmiklós, Bánffyhunyad, Tusnádfürdő, Balánbánya, Székelykeresztúr, Szentegyháza.

${ }^{6}$ Bajmok, Törökkanizsa, Bégaszentgyörgy, Magyarittabe, Párdány, Tamásfalva, Torak, Udvarnok, Vidapuszta, Hódság, Gombos, Csantavér, Csóka, Verbász, Krcedin, Novi Karlovci, Ingyija, Maradék, Csernye, Felsőhegy, Belgrád, Szabadka, Mitrovica, Hajdújárás, Beocsin,Lug, Rakovác, Martonos, Nagykikinda, Egység, Kisoroszi, Szaján, Magyarkanizsa, Horgos, Topolya, Bácskossuthfalva, Bajsa, Pacsér, Pannónia, Zentagunaras, Zombor, Béreg, Bezdán, Csonoplya, Doroszló, Gádor, Kerény, Küllőd, Monostorszeg, Nemesmilitics, Őrszállás, Regőce, Sári, Sztapár, Kelebia, Kevi, Királyhalma, Kishegyes, Bácsfeketehegy, Nagyfény, Kúla, Alibunár, Apatin, Bácskertes, Bácsszentiván, Szilágyi, Szond, Fehértemplom, Óbecse, Bácsföldvár, Péterréve, Ópáva, Ópázova, Petrőc, Sid, Szécsány, Szenttamás, Törökbecse, Bocsár, Karlova, Kumán, Zichyfalva, Antalfalva, Palics, Nagybecskerek, Hajdújárás, Magyarcsernye, Titel, Ada, Mohol, Törökfalu, Szeghegy, Muzslya, Padé, Temerin, Tavankút, Tornyos, Ruma, Újvidék, Versec, Zenta, Hertelendyfalva, Csóka, Zsablya, Palánka, Bács, Kevevára.

7 Példaként említhető a szentendrei Szabadtéri Néprajzi Múzeum (Skanzen), amely most építi Erdély tematikájú új tájegységét (htttps:// skanzen.hu/hu/a-skanzen/erdely/erdellyel-valik-teljesse-a-magyarsag-nepi-kulturajanak-bemutatasa). A több mint egy évtizedet átfogó szakmai-kutatási és fizikai-megvalósítási előkészületek során a Skanzen számos erdélyi kulturális szervezettel alakított ki kapcsolatokat.
} 
csatlakozását a hálózathoz. ${ }^{8} \mathrm{~A}$ tagsággal számos előny jár. A szervezet koordinációs segítséget nyújt a kiadványok digitalizálásában, vándorkiállítás-adatbázist múködtet, kölcsönösen ingyenessé tette a múzeumi belépést, kiadványcseréket és közös kiállítási projekteket kezdeményez. A történelminek nevezhető hálózatépítés eredményeként az MVMSZ-nek már 26 határon túli tagja van, továbbá összeállítottak egy adatbázist a Kárpát-medence magyar örökségének múzeumi szereplőiről, amelyben több mint 120 intézmény szerepel. ${ }^{9} \mathrm{Az}$ összefüggő Kárpát-medencei hálózat építése mellett elindult a regionális nemzetrészek informális hálózatosodása, még ha az eredmények egyelőre csak alig láthatóak. A nagy múltú Erdélyi Múzeum-Egyesület (EME) tevékenysége csak nevében szorítkozik a gyűjteményi kultúrára, valójában inkább egy akadémiai jellegű magyar tudományos társaság, és mint olyan, elsősorban a Magyar Tudományos Akadémiával ápol szoros szakmai kapcsolatokat. ${ }^{10} \mathrm{Az}$ EME mint kolozsvári székhelyű nonprofit kutatóintézet, az EISZ tagja is.

\section{KULTÚRHÁZAK}

A kultúrházak, vagy más kifejezésekkel múvelődési házak, közösségi terek, a határon túli magyar kulturális hálózat fontos, általában komplex feladatokat ellátó intézményei. Vannak települések, ahol része a könyvtár és az előadótér (színpad) is, vagyis a szabadidő-eltöltés különböző gyakorlatainak is teret ad. Kisebb termeiben különböző foglalkozások megtartására is lehetőséget kínál. A kisebb településekre jellemzőek e komplex, kultúrát közvetítő intézmények, a nagyobb városokban jellemzően különálló intézmények és épületek látják el ezeket a feladatokat. Az eddig tárgyalt intézménytípusok közül a kultúrházak körében a legalacsonyabb a hálózatosodás mértéke.

\footnotetext{
${ }^{8}$ A szervezet honlapjának címe: https://videkimuzeumok.hu. A Dr. Rosta Szabolcs elnök által aláírt felhívás részlete: „,Szervezetünk az eddigieknél is nagyobb, nyilvánosabb és szervezettebb nyitást kezdeményez határon túli intézmények felé, a »magyar vidéki múzeum « fogalmának határokat átívelő, nemzeti eszmévé emelésével. Célunk, hogy a Kárpát-medence magyar örökségének múzeumi szereplői számára elérhetővé váljanak mindazok az előnyök és lehetőségek, melyeket az egységes Magyar Vidéki Múzeumok Szövetségéhez való tartozás jelent. A szövetség ennek érdekében, jelen formában tagfelvételt hirdet. A meghívás határon túli, a magyar kultúra emlékeit, gyűjteményeit őrző, hivatalos múködési engedéllyel/alapító okirattal rendelkező muzeális intézmények számára szól. E levéllel, a szövetségünk tagságának határon túli kapcsolatrendszere alapján összegyűjtött, a Kárpát-medencei magyar identitás megőrzéséért munkálkodó intézményeket kerestük meg." ${ }^{9}$ Az adatbázisban szereplő múzeumok és közgyűjtemények helyszínei. Vastaggal szedve azon települések, amelyek múzeuma a Szövetség formális tagjává is vált, dőlt betűvel pedig azok, amelyek az EISZ hálózatának tagjai. Erdély (Partiummal és Moldvával): Arad, Nagyvárad (3), Kolozsvár, Nagybánya, Marosvásárhely (2), Csíkszereda, Gyergyószentmiklós, Sepsiszentgyörgy, Székelyudvarhely, Érkörtvélyes, Érmihályfalva, Érsemjén, Gálospetri, Szalacs, Mezőpetri, Nagyszalonta, Szatmárnémeti (2), Kisiratos, Csíkszentmiklós, Gyergyóremete, Györgyfalva, Csernáton, Inaktelke, Jegenye, Válaszút, Kászonaltíz, Kide, Küküllőpócsfalva, Korond, Kökényesd, Kőrispatak, Kraszna, Lövéte, Máréfalva, Méra, Lujzikalagor, Csíkszentdomokos, Parajd, Sarmaság, Sáromberke, Siménfalva, Szentegyháza, Zabola, Szék, Szilágysámson, Tordaszentlászló, Várasfenes, Avasújváros, Bogánd, Mezőpetri, Kézdivásárhely, Ottomány. Kárpátalja: Ungvár (3), Beregszász. Muravidék: Lendva, Dobronok, Kapornak. Vajdaság (Bánáttal): Szabadka (4), Topolya, Óbecse, Zenta (2), Pétervárad, Szivác, Temerin, Szenttamás, Újvidék, Zombor, Verbász, Nagybecskerek, Versec, Nagykikinda, Kupuszina, Szávaszentdemeter. Horvátország: Eszék. Felvidék: Pozsony, Galánta, Kassa, Fülek, Komárom, Rimaszombat (4), Ipolyság, Losonc, Kékkő, Érsekújvár, Dunaszerdahely, Nagymihály, Szenc, Párkány, Léva, Mikszáthfalva, Bátorkeszi, Bény, Búcs, Dunamocs, I polyszalka (2), Iza, Oroszka, Zalaba, Zselíz, Rozsnyó, Trencsén, Királyhelmec, Homonna, Tőketerebes. Burgenland: Alsóőr, Kismarton (2).
}

10 Ld.: https://eme.ro/ 


\section{FELSŐOKTATÁSI INTÉZMÉNYEK}

A határon túli magyar egyetemek és főiskolák a regionális kultúraépítés és -közvetítés fontos centrumai. Szerencsére a Kárpát-medencei szintű hálózatosodás e területen is előrehaladt. A Nemzetstratégiai Kutatóintézet 2018-2019-ben olyan kutatást szervezett, amelynek egyik célja a tematikus együttmüködés erősítése volt a felsőoktatás terén a Kárpát-medence szomszédos országaival. ${ }^{11} \mathrm{~A}$ kutatás fő célkitűzése a magyarországi felsőoktatási struktúrákban tapasztalható hiányok és fejlesztési szükségletek orvoslása volt határon túli magyar kitekintésű múveletekkel. A határon túli, magyar nyelvú képzést nyújtó egyetemek különféle konstrukcióval múködnek. A hálózatépítésre jó példa a Székelyudvarhelyi Egyetemi Központ (SZÉK), amely négy magyarországi felsőoktatási intézménnyel van kapcsolatban ${ }^{12}$, képzéseit a Magyar Akkreditációs Bizottság akkreditálta, ám a megszerzett diploma Romániában is érvényes. A Kárpát-medencei magyar felsőoktatási hallgatók legfontosabb érdekképviseleti szervezete a Hallgatói Önkormányzatok Országos Konferenciája (HÖOK), amely az utóbbi években egyre nagyobb hangsúlyt fektet a határon túli magyar egyetemisták és főiskolások hálózatának kiépítésére. A szervezeten belül Külhoni Régiót hoztak létre, és önálló tisztséget tölt be a Külhoni Programért felelős elnöki megbízott.

\section{EGYÉB CIVIL SZERVEZETEK ÉS KULTURÁLIS INTÉZMÉNYEK}

A határon túli magyar civil szervezetek felismerték, hogy az Európai Unió 2014-2020-as pénzügyi ciklusa számos lehetőséget kínált a határon átnyúló kulturális hálózatépítésnek. Eredményesen pályázott uniós forrásokra például a szlovákiai Nagykapos és Vidéke Társulás, amely honlapja ${ }^{13}$ szerint 14 - nagyrészt a határon átnyúló magyar-magyar kulturális hálózat építéséhez hozzájáruló - EU-s projektre nyert támogatást. A Magyarország Kormánya Emberi Erőforrások Minisztériuma által kiírt EFOP pályázatok keretében alkalom nyílt a nemzetközi, transznacionális együttmúködések támogatására, amely keretében több pályázat a Kárpát-medencei magyar-magyar kulturális kapcsolatok erősítését szolgálta. A civil szervezetek határon átnyúló hálózata sok esetben informális keretben ragadható meg.

A határon túli magyarok kulturális hálózatában fontos szerepet játszanak a különböző kutatási műhelyek. Kolozsváron működik a román állami fenntartású Nemzeti Kisebbségkutató Intézet, amely elsősorban az erdélyi magyarsággal kapcsolatos társadalomtudományi kutatásokat folytat. ${ }^{14}$ Ugyanitt, az egyetemi mühelyek mellett végez kutatási tevékenységet a Max Weber Társadalomkutatásért Alapítvány, amelynek célja a tudomány-, ok-

\footnotetext{
11 EFOP-3.10.1-17-00002, Id.: http://www.nski.hu/efop-3-10-1-17-2017-00002.html

$12 \mathrm{Az}$ Edutus Egyetem, a Pannon Egyetem Georgikon Kara, az Óbudai Egyetem és a Budapesti Gazdasági Egyetem felügyeli a kihelyezett képzéseket.

13 Ld.: http://www.nvt-magyarhaz.eu/

14 Ld.: http://ispmn.gov.ro/hun/
} 
tatás- és kutatásszervezés mellett az ismeretterjesztés, valamint a szakmai és gazdasági érdekképviselet. ${ }^{15}$ A KAM - Regionális és Antropológiai Kutatások Központja Csíkszeredában múködő társadalomkutató intézet. Önálló, független, nonprofit intézmény, amely kutatási programokból, megrendelésekből tartja fenn magát. A KAM tevékenységének legfontosabb terepe a székelyföldi térség. ${ }^{16}$ Felvidéken a somorjai központú Fórum Kisebbségkutató Intézet keretében folynak elsősorban a határon túli magyarsággal kapcsolatos kutatások. Szerbiában a Zentán működő Vajdasági Magyar Művelődési Intézet a nemzetrész magyarságának egyik legfontosabb kultúraszervező intézménye.

\section{MAGYARORSZÁG SZEREPE A HATÁRON TÚLI MAGYAR KULTURÁLIS HÁLÓZATÉPÍTÉSBEN}

Az eddigiekben tárgyalt hálózatosodási kezdeményezések mögött elsősorban magyarországi intézmények tevékenységét emeltük ki. Külön is hangsúlyozni kell Magyarország Kormánya szerepét, amely a nemzetegyesítés politikájának keretében kiemelt figyelmet szentel a határon átnyúló magyar hálózatok kialakításának és megerősítésének. A Külgazdasági és Külügyminisztérium alá tartozó Balassi Intézet a külföldi magyar intézetek kiépítésével és működtetésével az 1920-as évek klebelsbergi kulturális diplomácia célkitúzéseit újította fel. Az intézmények alapfeladata a nemzeti kulturális örökség megőrzése és széles körű megismertetése, Magyarország és a partnerország közötti kulturális diplomáciai kapcsolatok fejlesztése, a kulturális és tudományos nemzetközi együttműködések elősegítése, a magyar nyelvoktatás biztosítása, valamint a magyar kultúra és társadalom sokszínűségének bemutatása. Az intézetek egy része kulturális, oktatási és tudományszervezési feladataik ellátásán túl például könyvtárat, magyar nyelvoktatási központot, galériát tart fenn. A külföldi magyar intézetek hálózata mára világszerte 22 országban, 24 intézettel képviseli a magyar kulturális diplomáciát. A Külgazdasági és Külügyminisztérium emellett fenntart egy oktatási és kulturális feladatokat ellátó szakdiplomata hálózatot is. Az oktatási és kulturális feladatokat is ellátó diplomaták feladata, hogy a magyar kultúrát és oktatást népszerúsítsék olyan országokban, ahol a magyar kultúrának nincs intézményes képviselete. Szakmai irányításukat, valamint a szakmai tevékenységükhöz szükséges források fedezetét a Külgazdasági és Külügyminisztérium Kulturális és Tudománydiplomáciáért Felelős Államtitkársága és az azon belül működő Külföldi Magyar Intézetekért és Nemzetközi Oktatási Kapcsolatokért Felelős Helyettes Államtitkárság közösen biztosítja. Az első ún. oktatási-kulturális szakattasék immár több mint tíz éve, 2007-ben kezdték meg múködésüket, akkor még Pekingben, Sanghajban, Tel-Avivban, Belgrádban és Zágrábban. A hálózat 2008-ban Madriddal bővült, azóta pedig számos új helyen kezdett bele a Külgazdasági és Külügyminisztérium a magyar kultúra és oktatás megismertetésébe. A felsorolt állomáshelyek közül többnek is megváltozott a státusza - Pekingben, Belgrádban és Zágrábban megnyílt a magyar kulturális intézet. 2017-ben immár nyolc állomáshe-

\footnotetext{
15 Ld.: https://www.maxweber.ro/
}

16 Ld.: https://www.kamintezet.ro/ 
Iyen dolgozik oktatási és kulturális feladatokat ellátó diplomata: Ammanban, Bakuban, Kijevben, Madridban, Sanghajban, Sao Paolóban, Tel-Avivban és Tokióban. A szakdiplomaták múködésének jogi hátterét a 1434/2015 (VI.30.) kormányhatározat biztosítja. ${ }^{17}$ A Miniszterelnökség Nemzetpolitikai Államtitkársága különböző programok (elsősorban a Kőrösi Csoma Sándor Program és a Petőfi Sándor Program) keretében támogatja a határon túli magyarok kulturális önszerveződését. A Hagyományok Háza 2017-től a népi kultúra köré szervezett formális hálózatot épít a Kárpát-medencében. A Kárpátaljára, Erdélyre, Vajdaságra és Felvidékre kiterjedő munka elsősorban a rendezvényszervezés, a gyűjteményezés és az élő hagyományátadás (képzések) területein folyik. Kiemelt szerepet kap ebben az Erdélyi Hagyományok Háza Alapítvány, amely önálló egységként tervezi múködését. Az intézmény kolozsvári, marosvásárhelyi, székelyudvarhelyi és csíkszeredai területi irodákat fog létrehozni, központja Marosvásárhelyen lesz. Az alapítvány kilenctagú kuratóriumában az erdélyi hagyományápolás kiemelkedő személyiségei, a Sapientia Alapítvány és Erdélyi Magyar Tudományegyetem (EMTE) képviselői vesznek részt. ${ }^{18}$ Az Agrárminisztérium keretében felépített hungarikum mozgalom 2012-től szervezi a magyar értékek, a nemzeti kulturális örökség legitimálást, gyüjteménybe történő felvételét. A mozgalom hálózatépítése kiterjed a határon túli magyarokra is. Ennek keretében alakult meg a Horvátországi Magyar Nemzetrész Értéktár Bizottság, a Felvidéki Értéktár Bizottság, az Erdélyi Magyar Értéktár Bizottság, a Muravidéki Magyar Értéktár Bizottság, legvégül pedig a Kárpátaljai Magyar Értéktár Bizottság is csatlakozott. A külhoni nemzetrész értéktár az országhatáron túl, egy adott ország területén élő magyarságra jellemző nemzeti értékek közül az adott Külhoni Nemzetrész Értéktár Bizottság által külhoni értékké nyilvánított értékek adatait tartalmazó gyűjtemény. Érdemes áttekinteni, hogy a különböző külhoni nemzetrészekben mely szervezetek koordinálják a mozgalmat. Erdélyben a Kriza János Néprajzi Társaság; Felvidéken a Csemadok keretében működő Szlovákiai Magyar Művelődési Intézet; Horvátországban a magyar kisebbségi érdekvédelmi szervezet, a Horvátországi Magyarok Demokratikus Közössége; Kárpátalján a Kárpátaljai Népfőiskolai Egyesület; Muravidéken a Muravidéki Magyar Önkormányzati Nemzeti Közösség; Vajdaságban a Vajdasági Magyar Múvelődési Intézet; míg Burgenlandon a Burgenlandi Magyar Kultúregyesület vállalta az értéktárral kapcsolatos feladatokat. Az Agrárminisztérium keretében különböző pályázatokkal segítik a kulturális értékek ápolását. ${ }^{19}$ Az Európai Unió keretében is több olyan program múködik, amely hozzájárul a határon túli magyar kultúra hálózatosodásához. A Kreatív Európa Program ${ }^{20}$ mellett az Európa Kulturális Fővárosa Program is ide sorolható. ${ }^{21}$ 2021-ben Európa három kulturális fővárosa közül kettő (Temesvár és Újvidék - utóbbit az EU tagságra kandidáló ország képviseletében hívták meg) a Kárpát-medencében található, és jelentős magyar kulturális tradícióval bír.

\footnotetext{
17 Ld.: http://www.balassiintezet.hu/hu/nemzetkozi-kapcsolatok/szakdiplomatak/

18 Ld.: https://hagyomanyokhaza.hu/hu/node/4164

19 Legutóbb a HUNG-2020 kódú felhívás jelent meg a hazai és a külhoni nemzeti értékek, hungarikumok népszerüsítésének támogatására, már múködő helyi települési értéktárakkal együttműködésben települési, tájegységi értéktárak létrehozására, valamint a Kárpát-medencei hagyományos öltözet-kultúra továbbörökítésére. http://www.hungarikum.hu/sites/default/files/HUNG2020 felhivas.pdf

${ }^{20}$ Ld.: https://ec.europa.eu/programmes/creative-europe/

21 Ld.: https://ec.europa.eu/programmes/creative-europe/actions/capitals-culture en
} 


\section{KONKLÚZIÓ}

2010 óta Magyarország Kormánya kiemelt feladatának tartja a nemzetpolitikát, amely a határon túli magyarok kulturális hálózatának erősödéséhez vezetett. A korábban is létező, megannyi informális kapcsolatra formális, intézmények közötti kapcsolatok sokasága épült. A határon túli magyarok kulturális hálózata az anyaországgal szoros kapcsolatban vált mind láthatóbbá.

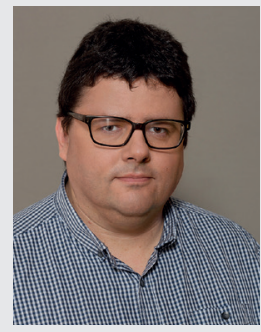

Dr. Bali János

Etnográfus, kulturális antropológus. Az Eötvös Loránd Tudományegyetem Bölcsészettudományi Kar Néprajzi Intézetének adjunktusa, a Nemzetstratégiai Kutatóintézet kutatási, stratégiai és koordinációs igazgatója. A Magyar Néprajzi Társaság Választmányának tagja, a Magyar Kulturális Antropológiai Társaság alelnöke, az MTA Köztestületének és az MTA Néprajzi Bizottságának tagja. 